\title{
Type I collagen formation in rat type II alveolar cells immortalised by viral gene products
}

\author{
R Matsui, R H Goldstein, K Mihal, J S Brody, M P Steele*, A Fine
}

\begin{abstract}
Background - Alveolar type II (T2) cells synthesise matrix proteins such as type IV collagen and fibronectin. In contrast, a fetal rat $\mathrm{T} 2$ cell line has been shown to synthesise type I and III collagen as well as type IV collagen. To study regulation of collagen production in $T 2$ cells, neonatal $T 2$ cells immortalised by adenoviral 12SE1A gene transfer were used. It was previously reported that this immortalised cell line (E1A-T2) retains epithelial features such as tight junctions and cytokeratins but also expresses mesenchymal features such as vimentin. Methods - Collagen production was examined in E1A-T2 and primary neonatal T2 cells using polyacrylamide gel electrophoresis. Electron microscopy was used to examine collagen deposition in E1A-T2 cell culture. To define the mechanism by which $\alpha_{1}(I)$ type I collagen gene expression was activated in E1A-T2 cells, a deletional analysis of $\alpha_{1}(I)$ promoter constructs linked to the bacterial chloramphenicol acetyltransferase gene was performed.
\end{abstract}

Results - E1A-T2 cells produced large amounts of type I collagen with a predominance of $\alpha_{1}(I)$ homotrimers; $\alpha_{2}(I)$ peptides were detected only in the cell layer. In contrast, primary neonatal rat T2 cell cultures produced a trace amount of type I collagen. Production of $\alpha_{1}(I)$ peptide chains (per $\mu \mathrm{g}$ DNA) in E1A-T2 cell cultures was 30 times higher than that observed in primary neonatal $\mathrm{T} 2$ cell cultures. Electron microscopy showed deposition of type I collagen fibrils in the extracellular matrix of E1A-T2 cell cultures. Transfection studies suggested at least two cis-acting elements which mediate increased $\alpha_{1}(I)$ gene expression in E1A-T2 cells.

Conclusions - These studies indicate that the E1A-T2 cell line may be useful for studying type I collagen gene regulation in alveolar $\mathrm{T} 2$ cells. These findings also raise the possibility that viral activation of type I collagen genes in alveolar epithelium may be involved in certain forms of pulmonary fibrosis.

(Thorax 1994;49:201-206)

Collagens are the major structural proteins of the lung, representing $15-20 \%$ of the total lung mass. ${ }^{1}$ Although lung cells synthesise multiple collagen types, ${ }^{23}$ type I collagen is the most abundant. Moreover, accumulation of type I collagen is characteristic of fibrotic lungs. ${ }^{4}$ Interstitial fibroblasts which comprise about $40 \%$ of the lung cell population are the major source of type I collagen. ${ }^{5}$ Other cell types such as smooth muscle cells and endothelial cells also synthesise type I collagen. ${ }^{3}$ It has recently been shown that a fetal rat type II (T2) cell line derived by clonal selection synthesised interstitial collagen type I, III, and $\mathrm{V}$ as well as type IV collagen. ${ }^{6}$ This suggests that alveolar epithelial cells may synthesise type I collagen under certain conditions.

Primary cultures of alveolar T2 cells have the capability of producing several types of extracellular matrix proteins including fibronectin, ${ }^{78}$ type IV collagen, ${ }^{79}$ and thrombospondin. ${ }^{7}$ However, identification of factors which regulate extracellular matrix in T2 cells has been limited by their in vitro behaviour; T2 cells in culture are characterised by lack of proliferation, cellular heterogeneity, and phenotypic instability. ${ }^{10}$ Our laboratory has developed a T2 cell line through retroviralmediated immortalisation with the adenoviral 12SE1A gene product and clonal selection. ${ }^{11}$ We have reported that T2 cells immortalised in this manner (this cell line will be referred to as E1A-T2) retain epithelial features of T2 cells such as tight junctions and cytokeratins, but also express vimentin which is characteristic of mesenchymal cells. ${ }^{12}$ The expression of both cytokeratin and vimentin has been noted in other epithelial or carcinoma cell lines ${ }^{1314}$ and in developmental tissues. ${ }^{15}$

To examine the hypothesis that an alveolar T2 cell line immortalised by a viral oncogene may synthesise type I collagen, we characterised collagen production in EIA-T2 cells. E1A-T2 cells produced large amounts of type I collagen with a predominance of the $\alpha_{1}(\mathrm{I})$ homotrimer. Increased production of $\alpha_{1}(\mathrm{I})$ homotrimers have been shown in association with embryonic tissue or cells, ${ }^{16-18}$ tumours, ${ }^{19} 20$ inflamed tissue, ${ }^{21}$ and various epithelial cell lines. ${ }^{6223}$ Our report suggests that this cell line may be used to study $\alpha_{1}(\mathrm{I})$ collagen gene regulation in alveolar $\mathrm{T} 2$ cells.

\section{Methods}

CELL CULTURE AND DERIVATION OF IMMORTALISED CELLS

T2 cells were isolated from 8-10 day old Sprague-Dawley rats according to the method described by Dobbs et $a l^{24}$ and immortalised by transfection with $12 \mathrm{~S}$ adenoviral E1A (12SE1A) gene as previously described. ${ }^{11}$ Briefly, T2 cells were exposed to conditioned 
media derived from cell line psi212E1A in the presence of polybrene $(8 \mu \mathrm{g} / \mathrm{ml}) \cdot{ }^{25} \mathrm{psi212SE} 1 \mathrm{~A}$ cells secrete a retroviral vector containing adenoviral 12SE1A cDNA sequences downstream from the long terminal repeat (LTR) of MOV9-2, ${ }^{26}$ and the selectable marker neomycin phosphotransferase gene downstream from the simian virus 40 (SV40) promoter. ${ }^{25} \mathrm{G} 418$ (Gibco) resistant fetal T2 cell clones were subcloned and then selected on the basis of positive immunofluorescence with anticytokeratin monoclonal antibodies AE1 and AE3 (ICN Inc). One of the 12SE1A expressing clones (E1A-T2) with positive immunofluorescence also demonstrated tight junctions by transmission electron microscopy. Notably, E1A-T2 cells could be serially passaged and were not capable of anchorage independent growth. For experiments, cell cultures were grown in Dulbecco's modified Eagle's medium containing $0.37 \mathrm{~g}$ sodium bicarbonate, $10 \%$ fetal bovine serum, 100 units penicillin $/ \mathrm{ml}$, $10 \mu \mathrm{g} / \mathrm{ml}$ streptomycin, $1 \%$ sodium pyruvate, $1 \%$ non-essential amino acid, and grown in a humidified $5 \% \mathrm{CO}_{2}$ incubator at $37^{\circ} \mathrm{C}$.

POLYACRYLAMIDE GEL ELECTROPHORESIS (PAGE) Proteins from confluent cultures $(35 \mathrm{~mm}$ dishes) were labelled in serum free medium containing $\left[{ }^{3} \mathrm{H}\right]$ proline $(5 \mu \mathrm{Ci} / \mathrm{ml})$ and ascorbate $(50 \mu \mathrm{g} / \mathrm{ml})$. After 24 hours medium and cell layer fractions were collected and processed independently. A solution of protease inhibitors yielding a final concentration of $10^{-4}$ $\mathrm{mol} / \mathrm{l}$ phenylmethylsulfonyl fluoride, $10^{-5}$ $\mathrm{mol} / 1$ hydroxymercurobenzonate, and $2 \times 10^{-3}$ mol/l EDTA was added. These fractions were then dialysed against water at $4^{\circ} \mathrm{C}$ until free $\left[{ }^{3} \mathrm{H}\right]$ proline was excluded. Samples were lyophilised and digested with pepsin at $4^{\circ} \mathrm{C}$ overnight and analysed by PAGE under nonreducing conditions. In one experiment pepsin digested proteins were also treated with highly purified collagenase (Advanced Biofacture, New York) before $7 \cdot 5 \%$ PAGE. Autoradiography was performed according to the method of Bonner and Laskey. ${ }^{27}$ To localise the position of pepsin treated type I collagen, pepsin treated radiolabelled type I collagen derived from rat skin was analysed on gels in parallel lanes.

DNA ASSAY

Cells were homogenised by Dunce homogeniser and incubated in 5\% perchloric acid at $80^{\circ} \mathrm{C}$ for 30 minutes. DNA was assayed by the diphenylamine colorimetric method ${ }^{28}$ Calf thymus DNA was used as a standard.

\section{PLASMID CONSTRUCTION}

Constructs containing varying lengths of the rat $\alpha_{1}(\mathrm{I})$ collagen gene promoter linked to the bacterial chloramphenicol acetyl transferase (CAT) gene were provided by Dr David Rowe (Department of Paediatrics, University of Connecticut) and Dr Barbara Smith (Department of Biochemistry, Boston University).
The longest promoter construct, ColCAT $3 \cdot 6$, contains 3250 base pairs of rat $\alpha_{1}(\mathrm{I})$ promoter upstream from 115 base pairs of the first exon linked to CAT ${ }^{29}$ ColCAT 2.4 was derived through digestion of ColCAT 3.6 by the restriction endonuclease Hind III. This deleted the 1224 base pair fragment extending from -3520 to -2296 . ColCAT 0.9 was constructed from a Pvu II digestion of ColCAT 3.6 which resulted in the deletion of base pairs -3520 to -944 . ColCAT $0 \cdot 2$ was constructed from a $\mathrm{Bgl}$ II digestion of ColCAT 0.9 resulting in a promoter element containing 225 base pairs of the promoter and 115 base pairs of the first exon. To compare transfection efficiency of these constructs, plasmids encoding $\beta$ galactosidase (pRSV- $\beta$-gal) were cotransfected as described previously. ${ }^{30} 31$

\section{TRANSIENT TRANSFECTION}

E1A-T2 cells were plated at a density of 800000 cells per $100 \mathrm{~mm}$ dish. After 24 hours $\mathrm{Ca}^{2+}$-DNA $(10 \mu \mathrm{g} / \mathrm{dish})$ precipitates were added to cells in a stepwise manner. ${ }^{32}$ Cultures were incubated overnight and then shocked with $15 \%$ glycerol. After washing cultures, fresh medium was added for an overnight incubation before protein extraction.

\section{CAT ENZYME ASSAYS}

Protein extracts were clarified by brief centrifugation and resuspended in $100 \mu 10.25 \mathrm{~mol} / 1$ Tris- $\mathrm{HCl}(\mathrm{pH} 7 \cdot 8$ ) and sonicated for 20 seconds. Protein concentrations were determined by the Bio-Rad protein assay solution in a standard protocol. To determine CAT activity, $0.25 \mu \mathrm{l}\left[{ }^{14} \mathrm{C}\right]$ chloramphenicol (Amersham) and acetyl coenzyme A (Pharmacia) were added to $100 \mu \mathrm{g}$ cell protein extract, or 0 or 0.5 units chloramphenicol acetyltransferase (Pharmacia), and incubated at $37^{\circ} \mathrm{C}$ for $4-6$ hours in $150 \mu \mathrm{l} 0.25 \mathrm{~mol} / \mathrm{l}$ Tris- $\mathrm{HCl}$ ( $\mathrm{pH} \mathrm{7.8)}$. These conditions were within the linear range of activity in these samples. The incubation mixture was then extracted with ethyl acetate. Acetylated and non-acetylated products were separated by thin layer chromatography (TLC) in a solution of chloroform/methanol (95:5). Acetylated and non-acetylated products separated by TLC were revealed by autoradiography and removed from TLC and counted.

\section{ELECTRON MICROSCOPY}

E1A-T2 cells were plated in $35 \mathrm{~mm}$ cultures and then grown in the presence of ascorbic acid for four days. Cultures were subsequently fixed at room temperature for two hours with a solution containing $2 \%$ glutaraldehyde and $2 \%$ tannic acid, post fixed with osmium tetroxide, embedded in epoxy resin, and then sectioned with $60-70 \mathrm{~nm}$ thickness.

\section{Results}

Collagen production was assessed in confluent cultures of immortalised E1A-T2 cell cultures 
by PAGE of pepsin digests of proteins radiolabelled with $\left[{ }^{3} \mathrm{H}\right]$ proline. E1A-T2 cells secreted several collagenous proteins into the medium. As shown in fig 1 , the predominant collagenous protein secreted into the medium was identified as the $\alpha_{1}(I)$ type I collagen chain. This band migrated to the same position as pepsin treated radiolabelled $\alpha_{1}(\mathrm{I})$ peptide derived from rat skin. We did not detect $\alpha_{2}(\mathrm{I})$ chains in the medium. In the cell layer the major pepsin resistant protein was also the $\alpha_{1}$ (I) chain. In addition, the cell layer contained a trace amount of $\alpha_{2}(I)$ chains. Densitometry indicated that the ratio of $\alpha_{1}(\mathrm{I})$ to $\alpha_{2}$ (I) chains in the cell layer was 8:1. Pepsin resistant proteins secreted into the medium or associated with the cell layer were sensitive to highly purified collagenase (fig 2). These results show that collagen synthesis in E1A-T2 cells is characterised by the predominant production of $\alpha_{1}(I)$ homotrimers and trace amounts of heterotrimers $\left(\left[\alpha_{1}(I)_{2} \alpha_{2}(I)\right]\right)$.

We compared collagen production in E1AT2 cells and non-immortalised primary neonatal T2 cells. For this study PAGE was performed on pepsin treated radiolabelled proteins derived from E1A-T2 cells and primary neonatal T2 cells normalised to DNA content $(2.5 \mu \mathrm{g})$. Densitometry showed that the band corresponding to the $\alpha_{1}(\mathrm{I})$ peptide in E1A-T2 cultures was 30 times greater than the $\alpha_{1}(I)$ band derived from primary $\mathrm{T} 2$ cell cultures (fig 3). The ratio of $\alpha_{1}(I)$ to $\alpha_{2}(I)$ in primary T2 cultures was approximately $2: 1$. Notably, we

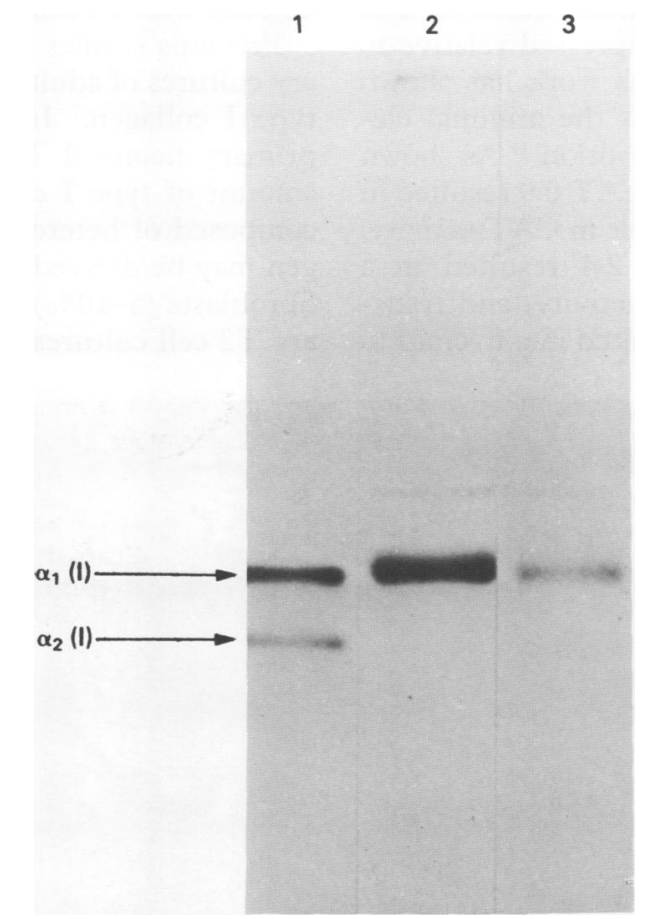

Figure 1 Autoradiograph of 7.5\% PAGE of E1A-T2 cellular proteins after limited pepsin digestion. Proteins from a single confluent culture ( $35 \mathrm{~mm}$ dish) of EIA-T2 cells were radiolabelled for 24 hours in serum free medium containing [ ${ }^{3} \mathrm{H}$ ] proline and ascorbic acid and then digested with pepsin before $P A G E$ analysis under non-reducing conditions. Lane 1 shows the position of radiolabelled $\alpha_{1}(I)$ and $\alpha_{2}(I)$ type I collagen peptides derived from pepsin treated rat skin, lane 2 shows collagenous medium proteins, and lane 3 shows collagenous medium proteins, and lane 3 shows
collagenous proteins derived from cell layer. The bands corresponding to the $\alpha_{1}(I)$ and $\alpha_{2}(I)$ peptide chains are indicated by arrows.

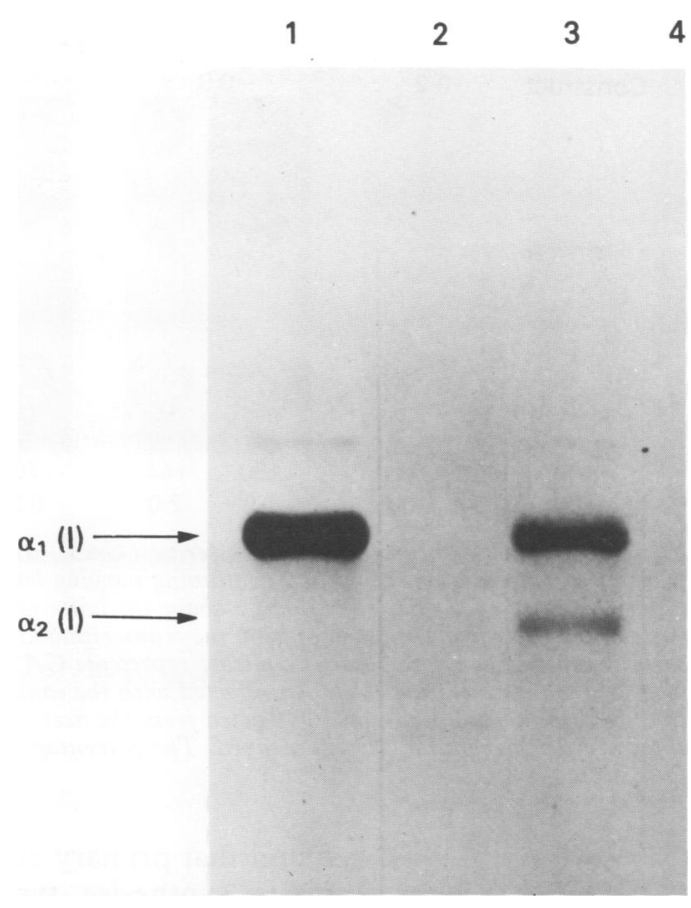

Figure 2 Autoradiograph of $7.5 \%$ PAGE of pepsin digested E1A-T2 cell proteins treated with or without collagenase. Lanes 1 and 2 show pepsin treated radiolabelled medium proteins. Lanes 3 and 4 show pepsin treated proteins derived from the cell layer. In lanes 2 and 4 proteins were exposed to collagenase before analysis.

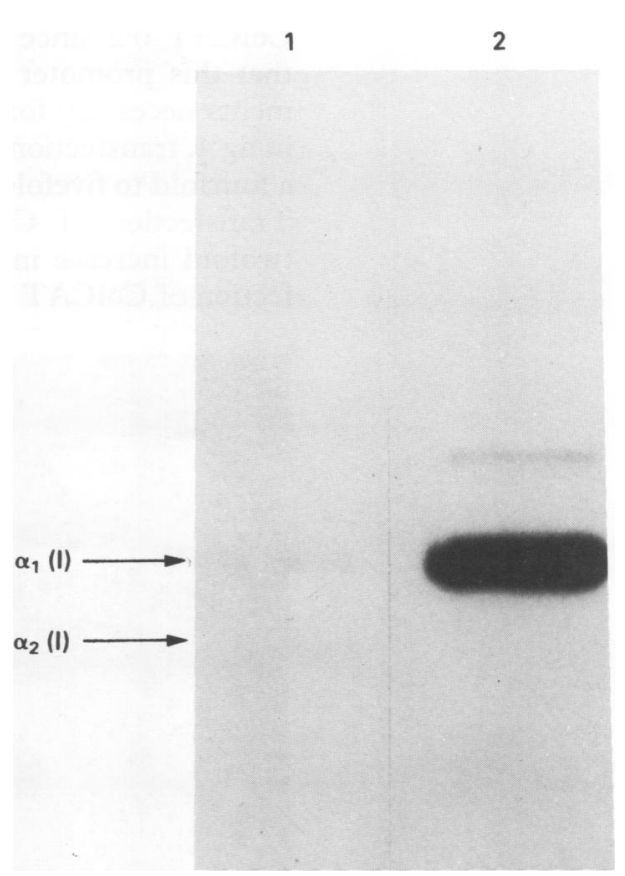

Figure 3 Autoradiograph of $7.5 \%$ PAGE of neonatal $T 2$ cell and EIA-T2 cell collagenous proteins. After 40 hours in culture primary $T 2$ cells reached confluence and were then radiolabelled in serum-free medium containing $\left[{ }^{3} \mathrm{H}\right]$ proline and ascorbic acid. After 24 hours, medium fractions were collected, dialysed, and digested with pepsin. The cell layer was harvested and used for DNA assays. ${ }^{28}$ Confluent cultures of EIA-T2 cells were treated in a similar manner. Equal aliquots of protein per $2.5 \mu \mathrm{g}$ cellular DNA were analysed. Lane 1 shows pepsin resistant proteins from primary neonatal $T 2$ cell cultures, and lane 2 shows pepsin resistant proteins from E1A-T2 cells. 

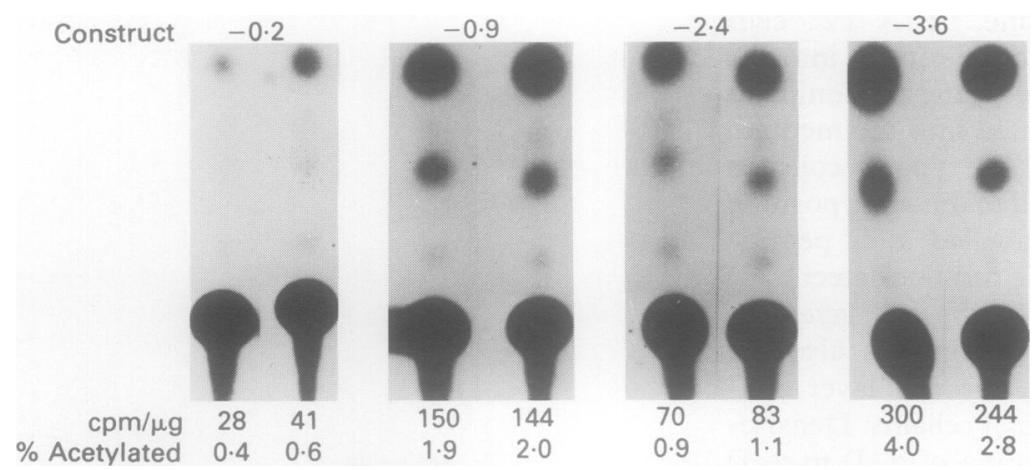

Figure 4 Chloramphenicol acetyl transferase (CAT) assay from E1A-T2 cells transfected with plasmid constructs containing varying lengths of the rat $\alpha_{1}(I)$ promoter linked to CAT. The numbers above the lanes represent the number of base pairs of $\alpha_{1}(I)$ promoter upstream from the transcriptional start site contained within each transfected construct. Each duplicate represents CAT assay results (see methods) from two separate culture dishes transfected with the same construct. For each lane, the $\mathrm{cpm} / \mu \mathrm{g}$ is the counts per minute extracted from the acetylated areas on the TLC plate expressed per ug cellular protein assayed. The percentage acetylation is indicated.

found that primary cultures of rat lung fibroblasts synthesise type I collagen with an $\alpha_{1}(\mathrm{I}): \alpha_{2}(\mathrm{I})$ ratio of $2: 1$ (data not shown). Since primary T2 cell cultures are composed of 90 $95 \% \mathrm{~T} 2$ cells and $5-10 \%$ fibroblasts, ${ }^{33}$ the type I collagen which was produced in primary $\mathrm{T} 2$ cultures may be derived from contaminating fibroblasts.

To localise $\alpha_{1}(\mathrm{I})$ collagen gene promoter regions activated in E1A-T2 cells, constructs containing varying lengths of the $\alpha_{1}(\mathrm{I})$ promoter linked to CAT were transfected into cells and measured in duplicate cultures. For these studies, activity is expressed relative to ColCAT 0.2 since previous work has shown that this promoter contains the minimal elements necessary for transcription. ${ }^{34}$ As shown in fig 4 , transfection of ColCAT 0.9 resulted in a fourfold to fivefold increase in CAT activity. Transfection of ColCAT 2.4 resulted in a twofold increase in CAT activity, and transfection of ColCAT 3.6 resulted in a fivefold to tenfold increase in CAT activity. These results suggest that at least two cis-acting elements, located between -225 and -944 and between -2296 and -3520 mediate increased $\alpha_{1}(\mathrm{I})$ gene expression in E1A-T2 cells. In addition, these results suggest the presence of an element located between -944 and -2296 which negatively regulates $\alpha_{1}(\mathrm{I})$ activity. Cotransfection of plasmids encoding $\beta$-galactosidase with subsequent $\beta$-galactosidase assays demonstrated no difference in transfection efficiency between $\alpha_{1}(\mathrm{I})$ promoter constructs.

To examine the morphological appearance of the extracellular matrix produced by immortalised E1A-T2 cells, electron microscopy was performed on E1A-T2 cells grown in the presence of ascorbic acid for four days. The arrow in fig 5a identifies type I collagen fibrils deposited in the extracellular matrix with the typical banding pattern characteristic of this matrix molecule..$^{35}$ Higher power magnification of these type I collagen fibrils is displayed in fig $5 \mathrm{~b}$. The arrow in fig $5 \mathrm{c}$ identifies the presence of tight junctions characteristic of epithelial cells.

\section{Discussion}

In this paper we report that a clonally expanded neonatal rat $\mathbf{T} 2$ cell line derived by retroviral mediated adenoviral 12SE1A gene transfer produces type I collagen with a predominance of $\alpha_{1}(\mathrm{I})$ trimers. $\alpha_{2}(\mathrm{I})$ peptides were not detected in the medium although a small amount was deposited in the cell layer.

Previous studies have suggested that primary cultures of adult $\mathrm{T} 2$ cells do not synthesise type I collagen. ${ }^{7}$ In contrast, we found that primary neonatal $\mathrm{T} 2$ cells produced a trace amount of type I collagen which was mostly composed of heterotrimer. This type I collagen may be derived from the small amount of fibroblasts $(5-10 \%)$ which contaminate primary $\mathrm{T} 2$ cell cultures. ${ }^{33}$

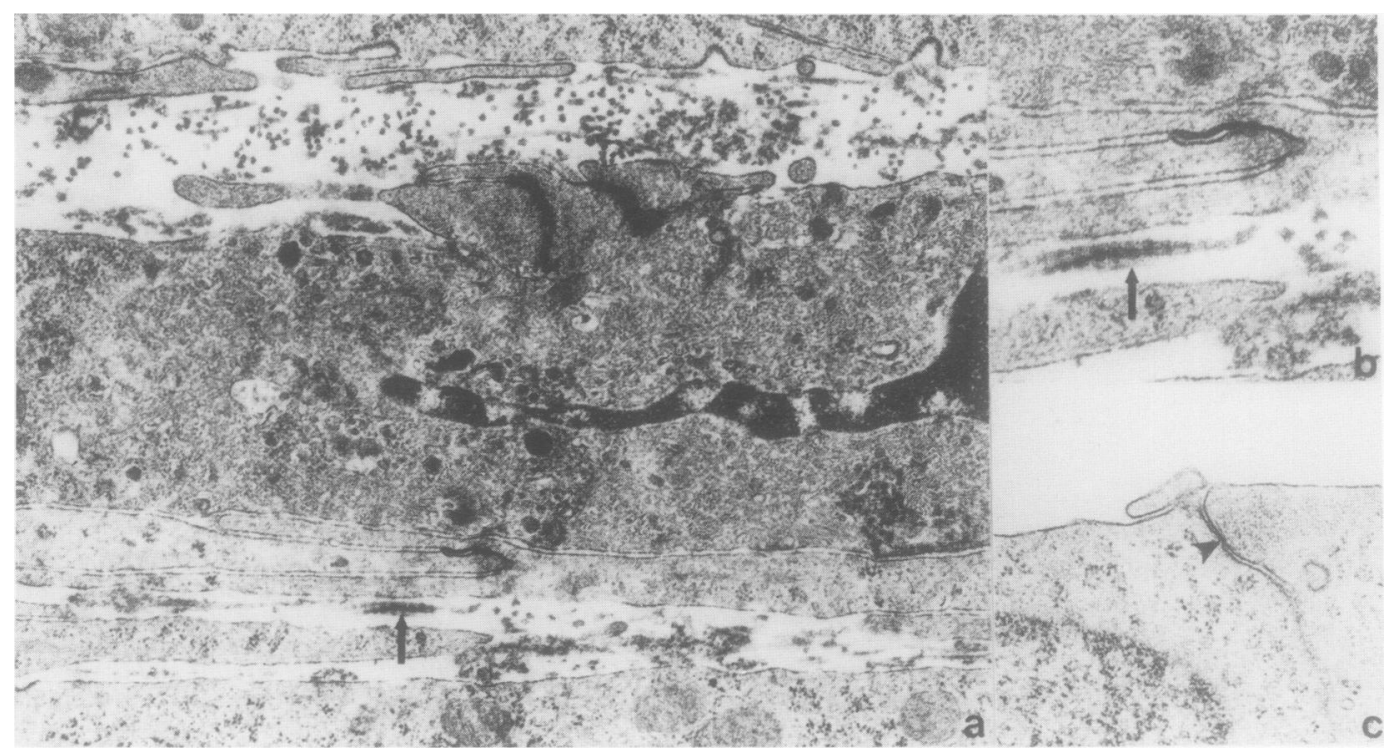

Figure 5 Transmission electron microscopy of E1A-T2 cells grown in the presence of ascorbic acid. (a) Collagen fibril deposited in extracellular matrix with banding pattern characteristic of type I collagen (arrow) (original magnification $\times 27000$ ). (b) Higher power view (original magnification $\times 50000$ ) of collagen fibril. (c) Tight junction (arrowhead) characteristic of epithelial cells (original magnification $\times 31000$ ). Reduced to $86 \%$ in origination. 
Besides E1A-T2 cells, a fetal T2 cell line defined on the basis of morphological criteria was shown to synthesise type I collagen including the $\alpha_{1}(\mathrm{I})$ trimer. $^{6}$ It is possible that these cell lines acquired mesenchymal features, such as type I collagen production, during the process of immortalisation. Notably, E1A-T2 cells express vimentin as well as cytokeratin. ${ }^{11}$ Viral gene mediated immortalisation may involve differentiation programmes which regulate epithelial mesenchymal transition.

We found that E1A-T2 cells synthesised predominantly $\alpha_{1}(\mathrm{I})$ homotrimers. Previous work has shown that $\alpha_{1}(I)$ trimers have the capacity to form fibrils and have the morphological characteristics of the native heterotrimer as defined by electron microscopy. ${ }^{35}$ In our studies electron microsocpy showed deposition of type I collagen molecules in the extracellular matrix of E1A-T2 cells. Since the PAGE of the cell layer proteins showed synthesis of $\alpha_{2}(I)$ molecules, we suspect that both the $\alpha_{1}(\mathrm{I})$ homotrimer and the heterotrimer were present within the extracellular matrix.

Our data suggest that immortalisation of T2 cells by adenoviral E1A12S gene activates production of $\alpha_{1}$ type I collagen peptides through a mechanism which involves increased gene expression. The adenovirus E1A protein has been found to stimulate transcription of early viral genes ${ }^{36}$ and also transactivate cellular genes. ${ }^{37} 38$ The trans-activating mechanism has not been clarified but does not involve direct interaction of the E1A protein with specific DNA sequences. ${ }^{37}$ Rather, E1A appears to activate genes indirectly through interaction with other trans-acting factors. ${ }^{3940}$

The transfection data indicate that E1A-T2 cells contain trans-acting factors capable of interacting with cis-acting elements in transiently expressed $\alpha_{1}(\mathrm{I})$ promoter constructs. These cis elements reside between -225 and - 944 base pairs, and between -2296 and -3520 base pairs. The location of these elements is different from the cis-acting element which mediates activation of rat $\alpha_{1}(I)$ gene promoter by transforming growth factor $\beta .^{30}$ Whether cis elements involved in activating the $\alpha_{1}(\mathrm{I})$ gene in E1A-T2 cells interact with known trans-acting factors is uncertain. We suggest that E1A-T2 cell line could be an in vitro system to study the regulatory mechanism of $\alpha_{1}(\mathrm{I})$ gene activation in T2 cells.

Interstitial pulmonary fibrosis is characterised by excess deposition of type I and type III collagen. ${ }^{4142}$ Experimental evidence suggests that increased type I collagen synthesis in the lung results from activation of lung fibroblasts by inflammatory mediators released during tissue injury. ${ }^{43-47}$ Although viral infections may be associated with development of interstitial fibrosis, ${ }^{4}$ viral gene products suppress type I collagen production when transfected into fibroblasts in culture. ${ }^{48-50}$ In situ hybridisation with adenovirus DNA suggested a relationship between adenoviral infection and bronchiolitis obliterans organising pneumonia, a lung disease with focal regions of fibrosis. ${ }^{51}$ Taken together, these studies lead us to speculate that viral activation of type I collagen genes in epithelial cells may have a role in excess deposition of type I collagen seen in pulmonary fibrosis.

This work was supported by United States Public Health Service Grant HL-46902-01, the Veteran's Administration Research Service, and the Massachusetts Thoracic Society.

1 Fulmer JD, Crystal RG. Biochemical basis of pulmonary function. In: Crystal RG, ed. The biochemical basis of pulmonary function. New York: Marcel Dekker, 1976:41966 .

2 Hance AJ, Bradley K, Crystal RG. Lung collagen heterogeneity. Synthesis of type I and type III collagen by rabbit and human lung cells in culture. $\mathcal{f}$ Clin Invest 1976;57:102-11

3 Kelly J. Collagen. In: Massaro D, ed. Lung cell biology. New York: Marcel Dekker, 1989:821-66.

4 Phan SH. Diffuse interstitial fibrosis. In: Massaro D, ed. Phan SH. Diffuse interstitial fibrosis. In: Massaro D, ed.
Lung cell biology. New York: Marcel Dekker, 1989:907-80. 5 Crapo JD, Barry BE, Gehr P, Bachofen M, Weibel ER. Cel number and cell characteristics of the normal human lung. Am Rev Respir Dis 1982;125:740-5.

6 Leheup BP, Federspiel SJ, Guerry-Force ML, Wetheral NT, Commers PA, DiMari SJ, et al. Extracellular matrix biosynthesis by cultured fetal rat lung epithelial cells. I Characterization of the clone and the major genetic types of collagen produced. Lab Invest 1989;60:791-807.

7 Sage H, Farin FM, Striker GE, Fisher AB. Granular pneumocytes in primary culture secrete several major components of the extracellular matrix. Biochemistry components of the

8 Rannels SR, Fisher CS, Heuser LJ, Rannels DE. Culture of type II pneumocytes on a type II cell-derived fibronectinrich matrix. Am f Physiol 1987;253:C759-C765.

9 Crouch EC, Moxley MA, Longmore W. Synthesis of collagenous proteins by pulmonary type II epithelial cells. $A m$ Rev Respir Dis 1987;135:1118-23.

10 Voelker DR, Mason RJ. Alveolar type II epithelial cells. In Massaro D, ed. Lung cell biology. New York: Marcel Dekker, 1989:487-538.

11 Steele MP, Levine RA, Joyce-Brady M, Brody JS. A rat alveolar type II cell line developed by adenovirus 12SE1A gene transfer. Am 7 Respir Cell Mol Biol 1992;6:50-6.

12 Franke WW, Grund C, Kuhn C, Jackson BW, Illmensee K. Formation of cytoskeletas elements during mouse embryogenesis III. Primary mesenchymal cells and the first genesis III. Primary mesenchymal cells and the first appearance of

13 Franke WW, Schmid E, Schiller DL, Winter S, Jarasch $\mathrm{ED}$, Moll $\mathrm{R}$, et al. Differentiation-related patterns of expression of proteins of intermediate-size filaments in tissues and cultured cells. Cold Spring Harb Symp Quant Biol 1981;56:431-53.

14 Boyer B, Tucker GC, Valles AM, Franke WW, Thiery JP. Rearrangements of desmosomal and cytoskeletal proteins during the transition from epithelial to fibroblastoid organ ization in cultured rat bladder carcinoma cells. $\mathcal{f}$ Cell Biol 1989;109:1495-509.

15 Page $M$. Changing patterns of cytokeratins and vimentin in the early chick embryo. Development 1989;105:97-107.

16 Jimenez SA, Bashey RI, Benditt M, Yankowski R. Identification of collagen $\alpha_{1}(I)$ trimer in embryonic chick tendons and calvaria. Biochem Biophys Res Commun 1977;78:1354 61

17 Little CD, Church RL, Miller RA, Ruddle FH. Procollagen and collagen produced by a teratocarcinoma-derived cell line, TSD4: evidence for a new molecular form of collagen. Cell 1977;10:287-95.

18 Crouch E, Bornstein P. Collagen synthesis by human amniotic fluid cells in culture: Characterization of a procollagen with three identical pro $x_{1}$ (I) chains. Biochemistry 1978;17:5499-509.

19 Moro L, Smith BD. Identification of collagen $\alpha_{1}(\mathrm{I})$ trimer and normal type I collagen in a polyoma virus-induced and normal type I collagen in a polyoma virus-induce

20 Shapiro FD, Eyre DR. Collagen polymorphism in extracellular matrix of human osteosarcoma. $\mathcal{F}$ Natl Cancer Inst 1982;69:1009-16.

21 Narayanan AS, Page RC, Kuzan F. Collagens synthesized in vitro by diploid fibroblasts obtained from chronically inflamed human connective tissue. Lab Invest 1978;39:615.

22 Smith BD, Niles R. Characterization of collagen synthesized by normal and chemically transformed rat liver epith elial cell lines. Biochemistry 1980;19:1820-5.

23 Creely JJ, Commers PA, Haralson MA. Synthesis of type III collagen by cultured kidney epithelial cells. Connect Tissue Res 1988;18:107-22.

24 Dobbs LG, Gonzales R, Williams MC. An improved method for isolating type 2 cells in high yield and purity. method for isolating type 2 cells in

25 Cone RD, Grodzicker T, Jaramillo M. A retrovirus expressing the $12 \mathrm{~S}$ adenoviral E1A gene product can immortalize epithelial cells from a broad range of rat tissues. Mol Cell Biol 1988;8:1036-44.

26 Korman AJ, Frantz JD, Strominger JL, Mulligan RC Expression of human class II major histocompatibility Expression of human class II major histocompatibility Sci USA 1987;84:2150-4. 
27 Bonner WM, Laskey RA. A film detection method for ritium-labeled proteins and nucleic acids in polyacrylamide gels. Eur F Biochem 1974;46:83-8.

28 Burton K. A study of the conditions and mechanism of the diphenylamine reaction for the colorimetric estimation of deoxyribonucleic acid. Biochemistry 1956;62:315-22.

29 Lichtler A, Stover ML, Angilly J, Kream B, Rowe DW. Isolation and characterization of rat $\alpha_{1}(\mathrm{I})$ collagen promoter. F Biol Chem 1989;264:3072-9.

30 Ritzenthaler J, Goldstein RG, Fine A, Lichtler A, Rowe DW, Smith BD. Transforming-growth-factor- $\beta$ activation elements in the distal promoter regions of the rat $\alpha$, type I elements in the distal promoter regions of the

31 Hall CV, Jacobs PE, Ringold GM, Lee F. Expression and regulation of Escherichia coli lacZ gene fusions in mammalian cells. $\mathcal{f ~ M o l ~ A p p l ~ G e n e t ~ 1 9 8 3 ; 2 : 1 0 1 - 9 . ~}$

32 Gorman CM, Moffat LF, Howard BH. Recombinant genes which express chloramphenicol acetyltransferase in mammalian cells. Mol Cell Biol 1982;2:1044-51.

33 Clement A, Campisi J, Farmer SR, Brody JS. Constitutive expression of growth-related mRNAs in proliferating and nonproliferating lung epithelial cells in primary culture: evidence for growth-dependent trans 34 Rippe RA, Lorenzen SI, Brenner DA, Breindl M. Regulatory elements in the 5 flanking region in the first intron contribute to transcriptional control of the mouse alph

35 Tkocz C, Kuhn K. The formation of triple-helical collagen molecules from $\alpha_{1}$ or $\alpha_{2}$ polypeptide chains. Eur $\mathcal{f}$ Biochem 1969;7:454-62.

36 Berk AJ. Adenovirus promoters and E1A transactivation. Annu Rev Genet 1986;20:45-79.

37 Simon MC, Kitchener K, Kao HT, Hickey E, Weber L, Voellmy R, et al. Selective induction of human shock gene transcription by adenovirus E1A gene products, including the 12S E1A product. Mol Cell Biol 1987;7:2884-90.

38 Simon MC, Fisch TM, Benecke BJ, Nevins JR, Heintz N. Definition of multiple, functionally distinct TATA elements, one of which is a target in the hsp70 promoter for ments, one of which is a target in the

39 Martin KJ, Lillie JW, Green MR. Evidence for interaction of different eukaryotic transcriptional activators with distinct cellular targets. Nature 1990;346:147-52.
40 Fang L, Green MR. A specific member of the ATF transcription factor family can mediate transcription activation by the adenovirus E1A protein. Cell 1990;61:1217-24.

41 Raghu G, Striker LJ, Hudson LD, Striker GE. Extracellular matrix in normal and fibrotic human lungs. Am Rev Respir Dis 1985;131:281-9.

42 Quinones F, Crouch E. Biosynthesis of interstitial and basement membrane collagens in pulmonary fibrosis. $\mathrm{Am}$ Rev Respir Dis 1986;134:1163-71.

43 Fine A, Goldstein RH. The effect of transforming growth factor- $\beta$ on cell proliferation and collagen formation by factor- $\beta$ on cell proliferation and collagen forma

44 Khalil N, Bereznay O, Sporn M, Greenberg AH. Macrophage production of transforming growth factor $\beta$ and fibroblast collagen synthesis in chronic pulmonary inflammation. f Exp Med 1989;170:727-37.

45 Piguet PF, Collart MA, Grau GE, Kapanci Y, Vassali P. Tumor necrosis factor/cachectin plays a key role in bleomycin-induced pulmonary fibrosis. $f$ Exp Med 1989;170:655-63.

46 Piguet PF, Collart MA, Grau GE, Sappino AP, Vassalli P. Requirement of tumor necrosis factor for development of
silica-induced pulmonary fibrosis. Nature 1990;344:245-7.

47 Raghow R, Irish P, Kang AH. Coordinate regulation of transforming growth factor $\beta$ gene expression and cell transforming growth factor $\beta$ gene expression and cell
proliferation in hamster lungs undergoing bleomycininduced pulmonary fibrosis. $\mathcal{f}$ Clin Invest 1989;84:183642.

48 Hata R, Peterkofsky B. Specific changes in collagen phenotype of BALB 3T3 cells as a result of transformation by sarcoma viruses or a chemical carcinogen. Proc Natl Acad Sci USA 1977;74:2933-7.

49 Sobel ME, Yamamoto $\mathrm{T}$, de Crombrugghe B, Pastan I. Regulation of procollagen messenger ribonucleic acid levels in Rous sarcoma virus transformed chick embryo fibroblasts. Biochemistry 1981;242:2678-83.

50 Schmidt A, Setoyama C, de Crombrugghe B. Regulation of a collagen promoter by the product of viral mos oncogene. a collagen promoter by the
Nature 1985;314:285-9.

51 Kuwano K, Hayashi S, Mackenzie A, Hogg JC. Detection of adenovirus DNA in paraffin-embedded lung tissues from patients with bronchiolitis obliterans and organizing pneumonia using in situ hybridization (abstract). Am Rev Respir Dis 1990;141:A319. 